\title{
Economic Institutions of the Converged Technological Platform for Sustainable Development
}

\author{
Irina Politkovskaya ${ }^{1,{ }^{*}, \text { Daniil Khvichiya }}{ }^{1}$, and Larisa Artamonova ${ }^{2}$ \\ ${ }^{1}$ Moscow Automobile and Road Construction State Technical University (MADI), 12531964 \\ Leningradsky av., Moscow, Russia \\ ${ }^{2}$ International Academy of Business and Management, 129594 5th passage Maryina Roshcha 15-a, \\ Moscow, Russia
}

\begin{abstract}
The study of the economic institutions of the diffusion of convergent technologies in the modern economy has a direct connection with sustainable development. The expansion of ultra-modern industries in the course of the "tertialization" of the economy (the growth of the sector of high-tech material and non-material production) makes it possible to significantly reduce resource consumption and the burden on the environment, while maintaining and increasing traditional economic values (income, well-being, employment, quality of life). The expansion of convergent technologies in technologically advanced countries is taking place in parallel with the formation of a "green" economy, which forms an independent technological platform for sustainable development, and may become the main one in the coming decades. The innovative upgrade of the extractive industries up to the Industry 4.0 level, based on this platform, requires special support from the state, primarily in the extractive countries. A special role in this process is assigned to the institutional support for the diffusion of convergent technologies, which is especially in demand in the Russian economy.
\end{abstract}

\section{Introduction}

Today, there is a prevalence of a technocratic approach to the study of the role of convergent technologies in the development of a modern economy and a neglect of the analysis of their role in the transition to sustainable development. This is largely a consequence of a separate approach to the convergent technological modernization of industry, "tertiarization" and the emergence of a "green" economy. In particular, the "green" economy is viewed as a special kind of economic system with complex interweaving of restrictions on resource consumption and recycling [1], while "tertialization" is, in fact, a reduction in material production [2]. In other words, these phenomena are not considered to be based on a fundamentally different technological basis than the one that was formed by the beginning of the 21 st century.

\footnotetext{
* Corresponding author: info@madi.ru
} 
Initially, technological convergence became the focus of sociological research in the 1990s (M. Castells) [3]. Later M. Rocko and W. Bainbridge defined convergent technologies as a synergistic result of the interaction of representatives of four areas of industrial science: nano and computational technologies, genetic engineering, neuroscience [4]. Since 2001, under the auspices of the US National Science Foundation, the so-called NBIC-initiative (nanotechnology-biotechnology-IT-cognitive sciences) has been put forward, which denotes a kind of convergent whole [5].

With regard to sustainable development, we define technological convergence as a process of transformation of the economy structure, initiated by the combination of the development of economic relations in the reproduction system (new forms of investment, innovations and new sources of capital, modifications of the combination of factors of production) and the merger of technologies. This process should radically change the scale and structure of resource consumption, bring closed-cycle production to the place of dominant industries, and separate the growth of human welfare from the expansion of used natural resources.

From the point of view of the development of productive forces, technological convergence means their new relocation - both within production chains and spatially (including extraterritorially, in a network form). As a result of such a relocation, clusters of a new type are being formed, in which producers of goods relative to the modern round of scientific and technological progress (such as the latest drugs, means of global information access, environmentally friendly energy sources, etc.) create an "off-center" network form of organizing the movement of resources, information and know-how, labor force, and coordinate their activities based on common economic incentives [6]. Such a relocation takes place as the formation of global network clusters of convergent technologies, using practically unlimited sources of investment in the global funds and a digitalized market of highly intelligent labor, creating products that exist mainly in an intangible form, being created and consumed extraterritorially [7-9].

\section{Materials and Methods}

The economies of technologically catching up countries (for example, BRICS members, including Russia) face the problems with formal institutions in the field of investor rights protection, so the best results of technological modernization are achieved in vertically integrated structures [10]. At the same time, monopoly sectoral holdings, especially with state participation, transfer to the economy outdated technologies that do not determine the trends of the "green" economy, and are unable to create conditions for the transition to sustainable development [11]. For example, one of the largest Russian state raw material corporations PJSC Gazprom - demonstrates a decrease in technological efficiency, even in relation to basic technologies for natural gas production (reduction of its production from 2007 to 2017 from 54 to 47,2 billion cubic meters, and shrinkage of the share in world gas market from 17.4 to $12.1 \%$ ) [12]. Therefore, the use of vertical integration to accumulate investment resources of industrial companies and direct them to fundamental research and R\&D is widespread in countries that have not reached the border of inter-industry transfer of convergent technologies.

On the contrary, in the economies of Eurasian countries that have entered the convergent technological border (Spain, France, Germany, the Netherlands, Singapore), the institutions of the investment system contribute to the development of flexible forms of accumulation and inter-sectoral distribution of capital, guaranteeing intellectual rent and the rights of investors to new technologies that do not have clear criteria for industry linkage (for example, nano-bio-convergent technologies in medicine and pharmaceuticals, microenergy, 
production of supernova polymers), ensure the market independence of innovators and help reduce the transaction costs of their commercialization [13].

According to E.A. Taran, V.A. Malanina, F. Casati, this logic is also valid in relation to the minimization of investment risks in the interaction of the production and scientific sectors of the economy and, therefore, can be translated into the investment component of a convergent-oriented structural policy [5]. That is, if in the Russian economy investment in catch-up technological modernization is provided by internal investments of vertically integrated state corporations, funds from state development institutions, budget allocations for financing state universities and research institutes, then advanced convergent technological modernization should be based on the diversification of financial risks by their insuring, guaranteeing, redistribution.

The convergent technology platform is designed to play a special role in producing countries. Thus, the Russian economy is not technologically identical to both technologically advanced countries (France, Germany, and the USA) and countries of accelerated innovative modernization (China, South Korea). The low accumulation rate leads to the consolidation of the low share of investment in R\&D in the Russian economy at the level of $0.7 \%$ of GDP for 1999-2017, while in Germany this indicator increased from 1.7 to $2.7 \%$, in China - from 0.8 to $2.5 \%$, in the USA it is at the level of 5.1-5.6\% [14]. Such "innovative nihilism" causes a ratio of investments in means of production and $R \& D$, atypical both for advanced and for countries catching up with "new industrialization". If in the Russian economy this ratio remains for 1999-2017 at the level of 30 times, then in China it decreased from 26 to 10 times, in Germany - from 9.3 to 5.8 times, in the USA - it is about 5 times [15]. Chronic "underinvestment" of the high-tech sector in the Russian economy fixes its all-encompassing dependence on natural rent, which exceeds intellectual rent (sales of intellectual products, including exports) by 31-34 times. This is thirty times higher than this value for the United States (a decrease in 1999-2017 from 6 to 1.5 times) Germany - (a decrease from 4 to 1.1 times) [16].

Attracting foreign technology-related investments in the Russian economy showed an upward trend in 1999-2011 (from 4.1 to $8.6 \%$ of GDP), which then changed to a downward trend (decline to $4.8 \%$ of GDP). At the same time, the share of foreign direct investment the main "conductor" of technological innovation in Russian industry - occupies a subordinate position, with a maximum of $2.8 \%$ in 2011 (2017 - 1.4\% of GDP), which is mainly due to speculative interest foreign investors to the Russian economy [17]. Against this background, the share of foreign direct investment in China's GDP significantly exceeds the Russian indicator (from 4.5 times in 2002 to 2 times in 2017), despite the presence of significant restrictions on foreign direct investors in China (for example, the permitted share of foreign participation in the capital of Chinese companies was increased from 25 to $50 \%$ only in 2015) [18]. Consequently, in contrast to technologically advanced and catching-up countries, the Russian economy has reduced opportunities for technological modernization due to foreign direct investment.

In the Russian economy, a certain reserve of institutions has been created that provide innovative development and investment in industrial modernization. They include action plans for import substitution in certain industries, (financial and organizational support for non-resource exports of the Russian Export Center, the Strategy for Scientific and Technological Development of the Russian Federation, National Technology Initiative [19].

At the same time, the development of investment in convergent technological modernization in the Russian economy is constrained by a number of institutional problems: 1. Rapid obsolescence of sectoral development strategies, developed in more than 40 since 2006 by departments of the Ministries of Economic Development, Industry and Trade, focused mainly on the development of traditional sectors and industries of the Russian economy, and not related to promising areas of their convergent technological modernization 
[20]. These strategies lack new technological benchmarks dictated by inter-sectoral transfer and global diffusion of innovations, which does not allow them to be characterized as institutions for initiating a convergent structural shift.

2. Slowdown in the development of the institutions of the investment system of the Russian economy, when most of them were created during the active transition from a pre-reform planned economy to a market one, i.e. more than 25 years ago (norms and rules governing the activities of commercial banks and stock exchanges, joint stock companies, fixing the concepts of know-how and copyright), or for macroeconomic stabilization. Accordingly, the institutions for investing innovations that correspond to convergent technological modernization, ensuring the convergence of the innovation and reproduction structure of the economy of Russia and technologically advanced countries (in the field of innovation consulting, international technology transfer, innovative cooperation between private firms and the state) have not yet been formed.

3. Inattention of the Central Bank to the problem of generating long-term investment resources for the implementation of convergent technological innovations, which is expressed in the divergence of goals and objectives of the Main directions of monetary policy, and overcoming a divergent structural shift. In particular, despite the negative real discount rate in the EU countries, the USA, Japan, established in the 2010s within the framework of "quantitative easing", the base rate of the Bank of Russia in the last 5 years has exceeded the inflation rate, which reduces the international competitiveness of the Russian industry [21]. In addition, in the Russian economy, the regulation of the stock market does not provide for the support of small joint-stock companies - micro-corporations, which are the main form of innovative enterprises in advanced countries and recipients of venture capital investments.

4. Insufficient volumes of investment by subjects of science and higher education (the budgets of Russian universities are 25-35 times less than in universities in the USA, France and Great Britain, and 12-15 times less than in China) [22]. This determines the low contribution of higher education and training of highly qualified personnel in postgraduate and doctoral studies to economic growth - through training personnel for innovative activities (in Russia it is 17 times lower than in China) [23-24]. Meanwhile, as studies have shown, with the expansion of convergent technologies, the contribution of scientific training to economic growth increases exponentially.

\section{Results and Discussion}

To reduce these obstacles to investing in the transfer of convergent technologies, we believe it is necessary to develop state and business institutions that ensure the development of a convergent technological platform and cross-platform interactions, inter-cluster formation of production chains and their investment. With regard to the institutions of the state, the most demanded, in our opinion, are the following.

First, the Federal List of Priority Converged Technologies, similar to the List of Breakthrough and Critical Technologies. With its help, it will be possible to determine the priorities of public investment, subsidies, preferential taxation and insurance of convergent technological innovations. It also requires the provision of support to Russian enterprises in the acquisition of high-tech foreign assets within the framework of interstate agreements.

Secondly, federal target programs in the field of inter-sectoral redistribution of capital, designed to integrate innovative and investment resources of technology platforms, raw material and processing state corporations, and entrepreneurship support funds. A special requirement for these targeted programs should be to take into account investment lags that increase with the integration of technological innovations from different industries into new convergent technological products, and the specific risks of their investment. Among such 
targeted programs, we include programs for the development of investment of funds of state holdings in priority convergent technologies from proposed list, attraction of technologically related direct investments (with the establishment of the most preferential tax regime), development of inter-cluster technological cooperation within the framework of public-andprivate partnerships.

Third, the development and adoption of laws on government guarantees and investment insurance for convergent technological innovations, as well as long-term bank lending to enterprises selling them. The legislative measures we propose to protect investors in converged technologies also include compensation for the costs of creating an innovative infrastructure (in the form of tax refunds, advance payments of future equipment purchase costs), guarantees of reimbursement of the value of firms' property in the event of a merger with state corporations or nationalization. It is necessary to legislatively concretize the ownership rights to convergent technologies, created not only in the present, but also in the future, which are difficult to assess using the existing industry criteria. It is also required to legally allocate publicly available technologies, which, being protected by patents, after being bought out by the state, can be used by small innovative firms without additional costs.

Fourth, the introduction of tax incentives that should encourage investment in mass commercialization and cross-sector transfer of converged technologies. First of all, the production of innovative products using convergent technologies should be exempt from VAT, and enterprises purchasing new equipment necessary for the production of such products (within the proposed list of priority convergent technologies) should be exempted from property tax, from customs duties upon import. Further, banks that provide long-term loans to private firms that develop and commercialize converged technologies should receive income tax relief and subsidized interest rates. In addition, it is necessary to use tax bonuses - additional income tax benefits in excess of the amount of profits reinvested by firms in convergent technological modernization. It also requires exemption from taxation of profits of industrial enterprises invested in R\&D of third-party convergent technology developers, if the latter transfer them ready-made know-how for implementation.

Fifth, the formation of the regulatory framework for the creation of non-state insurance companies to secure investment risks of venture funds and private innovative investors, and banking risks generated in the course of long-term lending to projects of convergent technological modernization of manufacturing enterprises.

\section{Conclusion}

The new sustainable development trend associated with the expansion of convergent technologies significantly enhances the productive forces of the green economy. At the same time, in the Russian economy, in which the commercialization and diffusion of convergent technologies is constrained by institutional problems, the prerequisites for the consolidation of technological lag and a slowdown in the transition to sustainable development are formed. The study of the institutional foundations of the transition of the Russian extractive economy to sustainable development in the system of technological convergence made it possible to identify problems associated with a contradictory differences to developed market systems, and determine the ways of their convergence in the course of the implementation of a number of institutional measures. An important role in this process is assigned to the development of institutions for the transfer and diffusion of convergent technologies, which expansion in advanced countries accelerates the transition to sustainable development. 


\section{References}

1. M. Yazevich, O. Kalinina, O.Zhironkina, Ecological consciousness in a shift of scientific paradigms E3S Web of Conferences 134, 03004 (2019)

2. S. Zhironkin, S. Demchenko, G. Kayachev, E. Taran, O. Zhironkina, Convergent and nature-like technologies as the basis for sustainable development in the 21st Century, E3S Web of Conferences 105, 03008 (2019)

3. F.G. Castles, Journal of European Social Policy 11, 195-211 (2001)

4. M.C. Roco, W.S. Bainbridge, Converging technologies for improving human performance: nanotechnology, biotechnology, information technology and cognitive science (Kluwer Academic Publishers, New York, 2003)

5. E.A. Taran, V.A. Malanina, F. Casati Economics and Innovation Management 4, 39-46 (2020) DOI: 10.26730/2587-5574-2020-4-39-46

6. M.A. Klimovich, Economics and Innovation Management 1, 18-25 (2019) DOI: 10.26730/2587-5574-2019-1-18-25

7. M. Cehlar, Economics and Innovation Management 3, 24-31 (2019) DOI: 10.26730/2587-5574-2019-3-24-31

8. D. Szurgacz, J. Brodny, International Multidisciplinary Scientific GeoConference Surveying Geology and Mining Ecology Management, SGEM 17(13), 47-54 (2017)

9. F.N. Abu-Abed, L.G. Naumova, Journal of Mining and Geotechnical Engineering 3, 2135 (2019) doi: 10.26730/2618-7434-2019-3-21-35

10. O.E. Kalenov, S.N. Kukushkin, Economics and Innovation Management 3, 88-96 (2020) DOI: $10.26730 / 2587-5574-2020-3-88-96$

11. A.V. Myaskov, S.M. Popov Economics and Innovation Management 1, 16-24 (2018) DOI: 10.26730/2587-5574-2018-1-16-24

12. A. P. Dzyuba, Economics and Innovation Management 1, 51-62 (2021) DOI: 10.26730/2587-5574-2021-1-51-62

13. K. Čulková, H. Pavolová, S. Khouri, L.G. Shut'ko, Economics and Innovation Management 3, 77-87 (2020) DOI: 10.26730/2587-5574-2020-3-77-87

14. S. Zhironkin, S. Demchenko, G. Kayachev, M. Ryzhkova, O. Zhironkina, E3S Web of Conferences, 41, 04011 (2018)

15. M.E. Konovalova, O.Y. Kuzmina, S.A. Zhironkin, Lecture Notes in Networks and Systems 84, 180-188 (2020)

16. S. Zhironkin, O. Aleshina, V. Gorev, Y. Gunyakov, O. Zhironkina, E3S Web of Conferences 105, 04001 (2019)

17. E.V. Shavina, Economics and Innovation Management 3, 4-13 (201)9 DOI: 10.26730/2587-5574-2019-3-4-13

18. M. Cehlár, P. Rybár, J. Mihók, J. Engel, Journal of Mining and Geotechnical Engineering 1, 4-31 (2020) doi: 10.26730/2618-7434-2020-1-4-31

19. National Technological Initiative. Russian Federation. URL: https://nti2035.ru/nti/

20. V. Trifonov, O. Loyko, D. Nesteruk, S. Zhironkin, E. Strekovtsova, AIP Conference Proceedings 1800, 050009 (2017)

21. S.A. Zhironkin, D. Cagáňová, Economics and Innovation Management 1, 20-30, (2020) DOI: $10.26730 / 2587-5574-2020-1-20-30$

22. V.V. Guzyr', Economics and Innovation Management 4, 4-19 (2019) DOI: 10.26730/2587-5574-2019-4-4-19 
23. S.K. Demchenko, J.J. Suslova, A.S. Yamschikov, I.R. Ruyga, T.A. Melnikova, Journal of Applied Economic Sciences 12(1), 194-205 (2017)

24. E.Y. Dotsenko, N.P. Ezdina, A.S. Khasanova, M.I. Khasanov, E3S Web of Conferences, 247, 01069 (2021) 